Goldschmidt 2021 Abstract

https://doi.org/10.7185/gold2021.5491

\section{Fluctuation of marine osmium isotope ratio during the Quaternary climate cycles}

YUSUKE KUWAHARA ${ }^{1}$, KAZUTAKA YASUKAWA ${ }^{1,2,3}$, KOICHIRO FUJINAGA ${ }^{2,3}$, TATSUO NOZAKI ${ }^{2,3,4,5}$, JUNICHIRO OHTA ${ }^{2,3,6}$, HONAMI SATO ${ }^{2,4,7}$, JUN-ICHI KIMURA $^{8}$, KENTARO NAKAMURA $^{1}$, YUSUKE YOKOYAMA $^{8,9,10,11}$ AND YASUHIRO KATO ${ }^{1,2,3,4}$

${ }^{1}$ Department of Systems Innovation, School of Engineering, The University of Tokyo

${ }^{2}$ Ocean Resources Research Center for Next Generation, Chiba Institute of Technology

${ }^{3}$ Frontier Research Center for Energy and Resources, School of Engineering, The University of Tokyo

${ }^{4}$ Submarine Resources Research Center, Research Institute for Marine Resources Utilization, Japan Agency for Marine-Earth Science and Technology

${ }^{5}$ Department of Planetology, Graduate School of Science, Kobe University

${ }^{6}$ Volcanos and Earth's Interior Research Center, Research Institute for Marine Geodynamics, Japan Agency for MarineEarth Science and Technology

${ }^{7}$ Department of Geosciences, University of Padova

${ }^{8}$ JAMSTEC

${ }^{9}$ Department of Earth and Planetary Science, Graduate School of Science, The University of Tokyo

${ }^{10}$ Graduate Program on Environmental Sciences, Graduate

School of Arts and Sciences, The University of Tokyo

${ }^{11}$ The University of Tokyo

Presenting Author: yusuke-kuwahara326@g.ecc.u-tokyo.ac.jp

The solid earth plays a major role in controlling Earth's surface climate. Volcanic degassing of carbon dioxide $\left(\mathrm{CO}_{2}\right)$ and silicate chemical weathering are known to regulate the evolution of climate on a geologic timescale $\left(>10^{6} \mathrm{yr}\right)$ [1], but the relationship between the solid earth and the shorter $\left(<10^{5} \mathrm{yr}\right)$ fluctuations of the Quaternary glacial-interglacial cycles is still under debate. We employed the paelo-seawater osmium isotope composition $\left({ }^{187} \mathrm{Os} /{ }^{188} \mathrm{Os}\right)$, as a proxy for the solid earth's response to the Quaternary climate change. The marine ${ }^{187} \mathrm{Os} /{ }^{188} \mathrm{Os}$ reflects the relative intensity of two dominant influxes to the ocean: radiogenic continental-derived materials $\left({ }^{187} \mathrm{Os} /{ }^{188} \mathrm{Os}=\sim 1.4\right)$ and unradiogenic mantle-like materials $\left({ }^{187} \mathrm{Os} /{ }^{188} \mathrm{Os}=\sim 0.126\right)$ such as hydrothermal fluids and cosmic dust [2].

Our analytical results of deep-sea sediments at ODP Site 834 in the South Pacific Ocean showed that the seawater ${ }^{187} \mathrm{Os} /{ }^{188} \mathrm{Os}$ has varied during the past 300,000 years in association with glacial-interglacial cycles [3]. We implemented marine Os isotope mass-balance simulations and revealed that the observed ${ }^{187} \mathrm{Os} /{ }^{188} \mathrm{Os}$ fluctuation cannot be explained solely by changes in global chemical weathering rate corresponding to the Quaternary glacial-interglacial climate cycles [3]. Instead, the fluctuation can be reproduced by taking account of short-term inputs of (i) radiogenic Os derived from intense weathering of glacial till during deglacial periods [4] and (ii) unradiogenic Os derived from enhanced seafloor hydrothermalism triggered by sea-level falls associated with increases of ice sheet volume [5]. Our results constitute the first evidence that ice sheet recession and expansion during the Quaternary systematically and repetitively caused short-term $\left(<10^{5} \mathrm{yr}\right)$ solid earth responses via chemical weathering of glacial till and seafloor magmatism. This finding implies that climatic changes on $<10^{5}$ yr timescales can provoke rapid feedbacks from the solid earth, a causal relationship that is the reverse of the longer-term $\left(>10^{6} \mathrm{yr}\right)$ causality that has been conventionally considered.

[1] Berner \& Kothavala (2001) Am. J. Sci. 301, 182-204. [2] Peucker-Ehrenbrink \& Ravizza (2000) Terra Nova 12, 205-219. [3] Kuwahara et al. (2021) Sci. Rep. accepted, [4] PeuckerEhrenbrink \& Blum (1998) Geochim. Cosmochim. Acta 62, 3193-3203. [5] Lund \& Asimow (2011) Geochem., Geophys., Geosys. 12, Q12009. 